\title{
Undergraduate Use Patterns of Newspapers on Microfilm
}

\begin{abstract}
This analysis, based on undergraduate use patterns of newspapers on microfilm at the Unicersity of Illinois, presents criteria, such as number of titles, dates requested, and existence of indexes, that should be considered when purchasing microfilmed newspapers for the highest possible benefit in terms of money spent. Statistics on use suggest that a user satisfaction level of almost 85 percent can be attained with a twenty-year backfile of twenty titles. The analysis presented is offered as one step in development of an acquisitions policy for newspapers on microfilm.
\end{abstract}

\section{I}

N RECENT YEARS newspapers have become increasingly important reference and research sources for 'a wide variety of users on college and university campuses. They provide original documentation for events that are too recent to be covered in monographs and professional journals or that have been bypassed by the traditional literature of history, political science, economics, and the other social sciences and humanities. Newspapers are particularly attractive and useful to undergraduates for course papers and class projects on a variety of subjects.

They do, however, present librarians with several unique problems. Because of their physical nature, storage and preservation are difficult. While microfilm does represent a solution, newspapers still present obstacles because of the high cost of microfilm runs and because of the lack of bibliographic control over their content. Moreover, since newspapers are general in their subject coverage, the determination of potential users is difficult. Undoubtedly, these factors contribute to the lack of professional literature on newspapers as library materials. ${ }^{1}$

Few libraries have developed guidelines

William J. Maher is newspaper librarian, University of Illinois at Urbana-Champaign, and Benjamin F. Shearer is government documents/ law librarian, East Tennessee State University, Johnson City, Tennessee. for a newspaper acquisitions policy, and this article will attempt to establish criteria for the development of a policy for newspapers on microfilm for undergraduate users in medium-size and small four-year colleges and universities. It is based on an analysis of undergraduate use at the newspaper library of the University of Illinois at Urbana-Champaign during the peak periods of the 1976/77 academic year.

While the conclusions presented here may not hold true for all libraries, the methodology will be valid and should direct librarians to the formulation of policies for the selection and purchase of newspapers on microfilm.

\section{USER SURVEY}

Before presenting use statistics and guidelines for acquisition, it is useful to describe the holdings and operations of the newspaper library at Illinois. With more than 63,000 reels of microfilmed newspapers, the library holds about 324 U.S. and 262 foreign titles. While the collection is particularly strong in Illinois titles, there are large microfilm runs for metropolitan newspapers in at least twenty-five states and in fourteen European and fourteen nonEuropean countries. There are strong holdings in such areas as labor, religious, literary, and black newspapers.

Because of an annual use of at least 
20,000 reels of microfilm, ${ }^{2}$ it is possible to analyze the exact nature of undergraduate interest in newspapers from statistics maintained on their use. When requesting film, all users complete a reference card on which they record the desired title and dates as well as information regarding their purpose and status (i.e., faculty, graduate student, undergraduate, and public).

These cards are used for all titles except the New York Times, the Chicago Tribune, and the Wall Street Journal. Because demand for these three titles is very high, they are stored in microfilm cabinets freely accessible to all patrons. All other titles are shelved in a restricted area, and patrons complete the reference card to request them. The cards provide the basis for the current analysis.

While the three most popular titles-New York Times, Chicago Tribune, and Wall Street Journal-are not included in these statistics, these titles are of such importance that they should be considered basic items for any college and university library. While the Chicago Tribune is heavily used at Illinois because of its local appeal, it is of national importance and should be a priority for many libraries, especially those in the Midwest. (Another regional substitute might be the Washington Post.) Any library not holding the New York Times and the Wall Street Journal should regard these as the first titles to acquire on microfilm. The New York Times, in particular, should be a top priority because of its importance and because it is indexed for its entire run. Beyond these basic titles, acquisitions policy can be determined best by an analysis of undergraduate use.

At the University of Illinois newspaper library, two months-November and Aprilconsistently account for the highest use of film for the period from 1973 to 1977 . This reflects a heavy demand by undergraduates in order to complete their course work as each semester draws to a close. While undergraduates annually account for 37 percent of use, during the months of November and April they account for 49 percent. This fact justifies the isolation of these months for the current study. The use during this period illustrates the importance undergraduates place on newspapers as re- search materials. The purpose of undergraduate use is also instructive: During November 1976 and April 1977, 85.5 percent of undergraduate use was for course papers (the other types of use recorded were "research for publication," "dissertation/ thesis research," "classroom use," and "other").

To identify those newspapers that will satisfy the most requests at the lowest cost, the following analysis studies titles requested, dates requested, and the importance of an index for use.

\section{TItles Requested}

Since newspapers on microfilm represent large investments, libraries must seek some assurance that the money spent yields an acceptable cost-benefit ratio when compared to the level of satisfaction of user needs. The case in favor of such basic titles as the New York Times, Wall Street Journal, and Chicago Tribune is clear, but the case for purchasing other newspaper titles is far more complex.

The geographical factor is perhaps the single most obvious element that influences undergraduate use of newspapers on microfilm. Thus the statistics presented here on titles requested at Illinois should not be taken as an inflexible acquisitions policy statement for other libraries. Some general principles on undergraduate use patterns do, however, emerge from these data, and these can be applied to any undergraduate library in terms of both titles and dates that may offer the greatest benefits for money spent.

Table 1 shows user demand according to titles requested during November 1976 and April 1977. As this table indicates, undergraduate use of newspapers on microfilm during the two peak use months of the year was restricted to forty-nine titles (excluding the New York Times, Wall Street Journal, and Chicago Tribune). Of the titles requested, thirteen (26.5 percent) were titles no longer published ("dead"), but in terms of total use these titles accounted for only sixteen requests ( 5.7 percent). The overwhelming number of requests were then for currently published ("live") titles.

The level of user satisfaction increases as more titles are added. The data show that 


\section{TABLE 1}

NewsPaper Titles ON Microfilm REQUESTED BY UNDERGRADUATES. NONEMBER 1976 AND APRIL 1977, BY NuMber of REQUESTS

\begin{tabular}{lc}
\hline \hline Title & $\begin{array}{c}\text { Number of } \\
\text { Requests }\end{array}$ \\
\hline 1. Daily Illini & 31 \\
2. Washington Post & 31 \\
3. Morning Courier (Champaign) & 30 \\
4. Los Angeles Times & 22 \\
5. News-Gazette (Champaign) & 19 \\
6. St. Louis Post-Dispatch & 13 \\
7. Chicago Daily News & 11 \\
8. Times (London) & 11 \\
9. San Francisco Chronicle & 8 \\
10. Chicago Defender & 7 \\
11. New York Amsterdam News & 7 \\
12. Atlanta Constitution & 7 \\
13. Chicago Sun-Times & 6 \\
14. Christian Science Monitor & 6 \\
15. Pittsburgh Courier & 6 \\
16. Village Voice & 5 \\
17. Los Angeles Sentinel & 4 \\
18. Detroit Free Press & 4 \\
19. Illinois State & \\
20. Journal-Register & 4 \\
21. New York Herald & 4 \\
22. Cleveland Plain Dealer & \\
23. Dallas Morning News & 27 \\
24. National Observer & 2 \\
25. Norfolk Journal \& Guide & 3 \\
26. Cincinnati Enquirer & 3 \\
27. Michigan Chronicle & 3 \\
28. New Orleans Times-Picayune & 2 \\
29-49. Twenty-one additional & \\
titles (12 “dead") with 1 & 3 \\
request each & 2 \\
Total requests & \\
\hline
\end{tabular}

47.7 percent of all requests could be satisfied with the top five titles, 65.6 percent with the top ten titles, 77.1 percent with the top fifteen, and 84.6 percent with the top twenty. Thus, only twenty-seven requests (9.7 percent) for "live" titles were not satisfied by the twenty most popular titles.

The factor of local bias is indeed quite important, as these statistics show. Three of the top five titles requested are local newspapers and by themselves constitute 28.7 percent of all requests. The Daily Illini is the student paper of the University of Illinois, and its heavy use is quite understandable. The Champaign-Urbana Courier and the News-Gazette are the two local papers. Language and country of origin are also sig- nificant factors. All of the top twenty titles requested were English-language titles, and the London Times was the only foreign title in the top twenty. Black newspapers also received relatively high usage-four of the top twenty were black papers (Chicago Defender, New York Amsterdam News, Pittsburgh Courier, and Los Angeles Sentinel).

The statistics on titles requested point to some important conclusions. A high level of user satisfaction can be attained with relatively few newspaper titles on microfilm. Aside from the school newspaper, six titles (including the two local papers; two titles from nearby metropolitan areas, such as the St. Louis Post-Dispatch and Chicago SunTimes; and two titles of national prominence, e.g., the Washington Post and the Los Angeles Times) could well satisfy 50 percent of all requests. It is necessary, therefore, that libraries consider geographical bias, country of origin, language, and special topics taught in the curricula (e.g., black studies) when deciding to purchase microfilmed newspaper titles to meet user demands as precisely as possible.

\section{DATES REQuested}

Consideration should also be given to the dates requested. An investment in large backfiles of even frequently used titles may not prove beneficial if the use of certain older dates is minimal.

Table 2 demonstrates that undergraduate requests for newspapers in microform decrease significantly for the years preceding 1969. In fact, 19.7 percent of all requests could be satisfied by keeping only a oneyear backfile in paper, thus avoiding a considerable expenditure for microfilm. This saving must, however, be weighed against the overall impracticality of storing and servicing newsprint. Problems of theft, mutilation, and preservation must be taken into account.

Assuming that libraries interested in building a research collection will consider purchasing all but current issues of newspapers in microform, it is instructive to analyze use in terms of five-, ten-, fifteen-, and twenty-year backfiles. It should be noted first, however, that only 22.9 percent of all citations were for dates before 1962, 
TABLE 2

DATES OF Undergraduate ReQuestS FOR NEWSPAPERS ON MICROFILM. NOVEMBER 1976 AND APRIL 1977

\begin{tabular}{|c|c|}
\hline Year & $\begin{array}{c}\text { Number of } \\
\text { Requests }\end{array}$ \\
\hline $\begin{array}{l}1976 \\
1975 \\
1974 \\
1973 \\
1972\end{array}$ & $\begin{array}{r}117 \\
71 \\
24 \\
40 \\
33\end{array}$ \\
\hline Total $1972-76$ & $\overline{285}(47.9 \%)$ \\
\hline $\begin{array}{l}1971 \\
1970 \\
1969 \\
1968 \\
1967\end{array}$ & $\begin{array}{l}34 \\
28 \\
27 \\
13 \\
13\end{array}$ \\
\hline $\begin{array}{l}\text { Total } 1967-71 \\
\text { Total } 1967-76\end{array}$ & $\begin{array}{l}115(19.3 \%) \\
400(67.2 \%)\end{array}$ \\
\hline $\begin{array}{l}1966 \\
1965 \\
1964 \\
1963 \\
1962\end{array}$ & $\begin{array}{r}15 \\
8 \\
8 \\
19 \\
9\end{array}$ \\
\hline $\begin{array}{l}\text { Total 1962-66 } \\
\text { Total } 1962-76\end{array}$ & $\begin{array}{r}59(10.0 \%) \\
459(77.1 \%)\end{array}$ \\
\hline $\begin{array}{l}1961 \\
1960 \\
1959 \\
1958 \\
1957\end{array}$ & $\begin{array}{r}7 \\
4 \\
5 \\
21 \\
\quad 7 \\
\end{array}$ \\
\hline $\begin{array}{l}\text { Total } 1957-61 \\
\text { Total } 1957-76\end{array}$ & $\begin{array}{c}\overline{44}(7.4 \%) \\
503(84.5 \%)\end{array}$ \\
\hline $\begin{array}{l}1947-56 \\
1937-46 \\
1927-36 \\
1917-26 \\
1907-16 \\
1897-1906 \\
1887-96 \\
1877-86 \\
1867-76 \\
1857-66\end{array}$ & $\begin{array}{r}40 \\
16 \\
1 \\
6 \\
4 \\
11 \\
11 \\
5 \\
1 \\
2 \\
6\end{array}$ \\
\hline $\begin{array}{l}\text { Total } 1857-1956 \\
\text { Total } 1857-1976\end{array}$ & $\begin{array}{r}\overline{92}(15.5 \%) \\
595(100 \%)\end{array}$ \\
\hline
\end{tabular}

and 8.7 percent for dates before 1946 . These are significant percentages of all citations, but the cost of filling user demands for citations prior to 1962 must be determined not only in relation to benefits but also in regard to the availability of older papers on some kind of cooperative loan arrangement.

Interlibrary loan and membership in systems, such as the Center for Research Libraries, are good examples of cooperative arrangements. Certainly most "dead" titles, which are seldom used, are available through cooperative lending. In short, there is little reason for a four-year college library to invest in long backfiles of newspapers on microfilm, especially if budgets are tight.

If a library is experiencing an especially severe budget crunch, it may choose to let its collection of newspapers in microform grow organically by ordering only current subscriptions. The cost of current subscriptions of filmed newspapers usually is significantly less than the cost of backfiles. For instance, based on the 1978 catalog of the Microfilming Corporation of America, a current subscription to the Atlanta Constitution costs $\$ 362$, whereas recent backfiles cost $\$ 540$ per year. In general, recent backfiles (within the past five years) tend to be about 40 percent more expensive than the current subscriptions themselves.

Although current subscriptions to approximately six titles may satisfy as much as $\mathbf{2 0}$ percent of user demands, more user satisfaction is attained as the size of the backfile increases. Thus, with a five-year backfile (1972-76), 47.9 percent of all requests could be filled. With the purchase of a ten-year backfile (1967-76), 67.2 percent of all user demands could be satisfied; with a fifteenyear backfile (1962-76), 77.1 percent of demands; and with a twenty-year backfile (1957-76), 84.5 percent of all demands.

These figures illustrate the types of questions librarians must ask themselves when deciding to purchase backfiles of $\mathrm{mi}$ crofilmed newspapers. For example, if 77.1 percent of all requests can be satisfied with a fifteen-year backfile, is the purchase of five additional years of a certain number of titles worth satisfying an additional 7.4 percent of user demands? These statistics indicate that a fifteen-year backfile in microform of the most frequently used newspapers (as determined by the factors described abovel offers a very high benefit for its cost. The money that could be spent on five more years of backfiles might be better used to purchase new titles.

When the data on titles requested and dates requested are brought together, a significant parallel emerges in the level of user satisfaction that can be attained with numbers of titles and the extent of backfiles. Summaries of user satisfaction by number of 
titles and size of backfile are shown in tables 3 and 4 .

The close relationship shown in tables 3 and 4 between titles and years requested for user satisfaction demonstrates the necessity of considering these two factors together when deciding to purchase newspapers in microform. For example, a 77.1-percent level of user satisfaction could not be attained merely by acquiring fifteen titles without also acquiring a fifteen-year backfile of these titles. The two criteria of number of titles and years of backfiles are inextricably related and must be considered jointly if a library wishes to obtain the highest level of user satisfaction for the money it spends on newspapers in microform.

TABLE 3

User Satisfaction by Titles Held

\begin{tabular}{cc}
\hline $\begin{array}{c}\text { Percent of } \\
\text { Requests } \\
\text { Answered }\end{array}$ & $\begin{array}{c}\text { Number } \\
\text { of } \\
\text { Titles }\end{array}$ \\
\hline $47.7 \%$ & 5 \\
$65.6 \%$ & 10 \\
$77.1 \%$ & 15 \\
$84.6 \%$ & 20 \\
\hline
\end{tabular}

TABLE 4

User Satisfaction bi Years ReQtested

\begin{tabular}{cc}
\hline \hline $\begin{array}{c}\text { Percent of } \\
\text { Requests } \\
\text { Answered }\end{array}$ & $\begin{array}{c}\text { Years } \\
\text { of } \\
\text { Bachfile }\end{array}$ \\
\hline $47.9 \%$ & $5(1972-76)$ \\
$67.2 \%$ & $10(1967-76)$ \\
$77.1 \%$ & $15(1962-76)$ \\
$84.5 \%$ & $20(1957-76)$ \\
\hline
\end{tabular}

\section{ROLE OF INDEXES}

Date and number of titles are important considerations in acquisitions policy, but accessibility is equally significant. Newspapers are a major source of information on numerous subjects of great interest to undergraduates. They do, however, present problems for bibliographical control because they are comprehensive in their subject coverage.

There are no indexes covering all newspapers, with the exception of microform series, such as Newsbank, which contain topically arranged clippings from several newspapers. While such collections do provide subject access to newspapers, their coverage is not deep and the subject categories are not likely to be of long-term interest to serious researchers. Moreover, their cost (about $\$ 1,000$ per year for Newsbank) may seem high for the benefit they bring. ${ }^{3}$

Thus adequate access to newspaper accounts on a given subject can be obtained only by the use of the available indexes for individual titles. Even then, the researcher is still confronted with a serious problem because of the lack of indexes for all but the most recent years of most newspapers. While the New York Times and the London Times are indexed for their entire runs, most metropolitan U.S. newspapers were not indexed until about 1970 .

It is reasonable to argue that the existence of an index will contribute to more requests for a given title, and statistics at the University of Illinois support this conclusion. Table 5 describes the relation of use of indexed papers to use of papers not indexed.

These statistics lead to several important conclusions. First, for dates requested within the past ten years, indexed titles account for more than one-half of all newspapers used. The average beginning date of most newspaper indexes is 1970 and is calculated on the following titles: Atlanta Constitution (index begins 1971), Index to Black Newspapers (1977), Christian Science

TABLE 5

INDEXED NEWSPAPERS SHARE OF TOTAL USE

\begin{tabular}{lc}
\hline \hline Year Requested & $\begin{array}{c}\text { Percent } \\
\text { of Use }\end{array}$ \\
\hline 1976 & $78.6 \%$ \\
1975 & $59.3 \%$ \\
1974 & $62.5 \%$ \\
1973 & $60.9 \%$ \\
1972 & $82.6 \%$ \\
$1972-76$ average & $68.7 \%$ \\
1971 & $39.1 \%$ \\
1970 & $52.4 \%$ \\
1969 & $36.0 \%$ \\
1968 & $50.0 \%$ \\
1967 & $57.1 \%$ \\
$1967-71$ average & $46.9 \%$ \\
$1967-76$ average & $57.8 \%$ \\
1966 & $50.0 \%$ \\
1965 & $42.9 \%$ \\
1964 & $50.0 \%$ \\
1963 & $5.3 \%$ \\
1962 & $1.0 \%$ \\
$1962-66$ average & $29.8 \%$ \\
\hline
\end{tabular}


Monitor (1950), Daily Illini (1961), Journal of Commerce (1976), Los Angeles Times (1970), Minneapolis Star and Tribune (1971), National Observer (1969), St. Louis newspapers (1975), San Francisco Chronicle (1970), New Orleans Times-Picayune (1972), and Washington Post (1971). The New York Times, Times of London, and Wall Street Journal were excluded from the average. Thus it would be more appropriate to use the $1972-76$ average ( 68.7 percent) as indicative of undergraduate preference for indexed titles.

In view of this, formulators of acquisitions policy should be very cautious about the purchase of newspapers on microfilm unless an index is available and also purchased. While the cost of indexes is high (averaging about $\$ 185$, or one-half of the cost of many film subscriptions), they clearly contribute to a large part of undergraduate use of newspapers in microform. ${ }^{4}$

To a large extent, the purchase of an index for a title already held is preferable to acquiring new titles. For example: If a library were receiving the Washington Post and the St. Louis Post-Dispatch at a total cost of $\$ 876$ and were considering the purchase of another title such as the TimesPicayune at a cost of $\$ 390$, it would be better advised to use that money for the indexes to the Post and the Post-Dispatch. Thus the selection of titles would be more limited, but access would be simplified and user satisfaction could be increased. If a library cannot bear the cost of monthly and/or quarterly indexes, it may consider purchasing only annual cumulative updates when these are available separately.

It is logical to assume that overall use of newspapers will increase with the presence of indexes. There is, however, no statistically valid trend in the increase of use with the availability of more indexes. Any appearance of an increase in use with the presence of more indexes since 1970 must be tempered by the fact that more recent years are generally more desirable (as illustrated in table 2).

For an accurate appraisal of the effect of indexes on overall use, it will be necessary to wait an additional five years when the use for the period 1972-76 is not influenced so heavily by its recency. While it is not possible to show an overall rise in use because of indexes, there is a demonstrable increase in the preference for indexed newspapers. This would seem to be a natural reflection of the greater availability of indexes since 1970.

Considering the importance of indexes for the use of newspaper titles, one would be inclined to purchase only indexed titles. Indexing should not, however, be the sole criterion because certain titles (e.g., those from many major U.S. cities) will be heavily used despite the lack of an index.

Of the twenty most requested titles listed in table 1 , only eight ( 40 percent) were indexed at the time of use (four of the titles were black newspapers that have since been covered by the Index to Black Newspapers). The fact that 60 percent of these twenty most-requested titles were not indexed should cause librarians to think carefully before refusing to purchase any nonindexed titles. Of the remaining twelve titles, five (two from Champaign-Urbana, two from Chicago, and one from Springfield, Illinois) are "locally" focused papers that have no index. If these five "local" newspapers were excluded from the analysis of the relation of indexes to most-used titles, indexed papers would account for 53.5 percent of the fifteen most-requested papers.

It should also be emphasized that 68.7 percent of all use of newspapers covering the years $1972-76$ is in indexed titles, even if indexed papers account for only 40 percent of the twenty most-requested titles. Thus if a library were contemplating the purchase of two papers of equal stature, one indexed and the other nonindexed, the indexed title should be preferred to achieve greater patron satisfaction. Moreover, the availability of an index is of crucial importance in the acquisition of papers from other than local areas. We should caution that while these statistics show the importance of indexes, an index should be only one factor in the decision to purchase a given title.

\section{Conclusion}

Our investigation has shown a strong relationship between certain variables (titles, dates, and existence of an index) and the use of microfilmed newspapers by undergraduates. We are convinced that these fac- 
tors suggest a methodology for the development of an acquisitions policy for newspapers on microfilm in four-year colleges and universities. These statistics show that almost 85 percent of all undergraduate demands can be satisfied with a twenty-year backfile of twenty titles, and an indexed newspaper will probably be preferred by a ratio of two to one. Admittedly, at an average cost of $\$ 263$ per year per title, this high a level of satisfaction would be an expensive proposition. ${ }^{5}$ The cost of high levels of user satisfaction raises an important, but often neglected, question: What is an acceptable level of user satisfaction?

Every library would naturally like to aim at 100 percent user satisfaction, but such a goal is unrealistic. In fact, even the 80percent level comes at a rather high price. Consequently, librarians must begin to address the question of realistic levels of user satisfaction in a systematic fashion. User satisfaction should always be considered in an institutional context, that is, in relation to factors such as budget, location, and par- ticipation in cooperative programs. A small college library with a severely restricted budget and few possibilities for cooperative arrangements may be giving the best possible service and still achieve only 50 percent user satisfaction.

Once a library has decided the level of user satisfaction it should attain, the analysis presented here will provide guidelines for an acquisitions policy for microfilmed newspapers. This study, however, is based on only one library and aimed solely at undergraduate use. While our conclusions will be useful to a number of institutions, they have certain limitations that suggest new directions for research. These would include study of use at other newspaper libraries to corroborate these findings, study of faculty and graduate student use patterns, and a follow-up study in about five years to obtain a better understanding of the effects of the availability of indexes on newspaper use. We hope the present analysis will encourage others to look more closely at newspaper use to satisfy research needs.

\section{REFERENCES}

1. A search of Library Literature from 1970 to 1978 renders only a handful of citations under the category of "Newspapers," and none of these address the question of use patterns. Mark Yerburgh's recent article "Academic Libraries and the Evaluation of Microform Collections," Microform Review 7:14-19 (Jan.Feb. 1978), is a first step in recognizing the necessity of evaluating microfilm collections in terms of "cost/benefit." However, the article concerns only microfilm collections in general and does not address specific problems of newspapers.

2. "Newspaper Library Annual Report, 1976-77," compiled by Charles B. Elston, newspaper librarian at Illinois from 1971 to 1977 . By establishing various procedures for keeping statistics, Elston has laid the basis for the data used in the present analysis.

3. Anita C. Milner's recently published Newspaper Indexes (Metuchen, N.J.: Scarecrow,
1977) is an excellent survey of newspaper indexes and includes both published indexes and unpublished ones (largely clipping files). A reading of her list of titles with published indexes would illustrate the overall lack of adequate bibliographic control of newspapers.

4. The indexes included in this average price are Atlanta Constitution, Index to Black Newspapers, Christian Science Monitor, Los Angeles Times, Minneapolis Tribune, New York Times, Washington Post, Chicago Tribune, San Francisco Chronicle, Times-Picayune, and St. Louis Post-Dispatch.

5. This average of $\$ 263$ for twenty titles includes four black newspapers at a relatively low cost ranging from $\$ 17$ to $\$ 55$ each. If these were excluded, the average cost would rise to $\$ 321$ per title per year, based on current subscription prices. This higher figure is probably more realistic. 